\title{
CLASS AND GENDER - THE REPRESENTATION OF WOMEN IN KINGSLEY AMIS'S LUCKY JIM
}

\author{
MILICA RAĐENOVIĆ \\ "Dr Lazar Vrkatić" Faculty of Law and Business Studies \\ 76, Oslobodenjia Blvd 21000 Novi Sad, Serbia \\ radjenovic.mi@gmail.com
}

\begin{abstract}
Lucky Jim is one of the novels that mark the beginning of a small subgenre of contemporary fiction called the campus novel. It was written and published in the 1950s, a period when more women and working-class people started attending universities. This paper analyses the representation of women in terms of their gender and class.
\end{abstract}

Keywords: campus novel, class, gender.

\section{Introduction}

After six years of war, Great Britain was hungry for change and craved a more egalitarian society. After the Labour Party came to power in July 1945 with a huge parliamentary majority, the new government started paving the way for a Welfare State, which involved the expansion of the system of social security, providing pensions, sickness and unemployment benefits, a free National Health Service, the funding and expansion of the 
secondary school system, and giving poor children greater opportunity to attend universities. The Conservative Party returned to power in 1951 but did not make any changes to the measures that brought about the creation of the Welfare State (Davies 2000:51). Once a great world power turned to reshaping its society, in which the class system would become a thing of the past, its people believed that they were living in a country that was going through great changes (Brannigan 2002:3). The Education Act of 1944 was intended to open universities to everyone and thus expand the trend of educational opportunities to the less privileged in the society. The resulting increase in the number of students led to an expansion of the English university system. Many working- or lower-middle class students found themselves in an unfamiliar environment that did not seem ready to accept them (Womack 2002:28-29).

In the 'fifties of the $20^{\text {th }}$ century, Lucky Jim was often regarded as an example of a novel about class conflict at university (Fallis 1977:65). Amis himself, however, believed that the book dealt primarily with questions of character (Keulks 2003:108).

Elaine Showalter has stated that "part of what makes Lucky Jim seem contemporary is the presence of women on the faculty" (2005:25). Unfortunately, their representation is not very flattering. In a cast in which good and evil seem to be easily detectable and separable, as in a fantasy tale (Salwak and Koger 2001:12), it is interesting to observe the way women are portrayed. In the 'fifties it was still commonplace to think women could either work or be happily married with children (Spencer 2005:1). Nevertheless, most feminist writers of the 'fifties believed they were living in an age in which greater equality between women and men had been 
achieved (Brannigan 2002: 68). The 'fifties have been perceived "as a decade of quietism for feminism" (Brannigan 2002:71).

\title{
2.1 The Angry Young Men
}

The idea of a new society required a new voice, new literature. A new generation of writers caught the attention of the public in the 'fifties the group of poets known as the Movement and the writers who were dubbed by the media the Angry Young Men (Brannigan 2002:3). The Angry Young Men came from working-class or lower-middle-class backgrounds and attended universities but refused to become traditional highbrow gentlemen (Salwak and Koger 2001:7). Their style was distinctly different from the style of the prewar experimental novels and their mode of writing was called realistic or common-sense (Salwak 2005:22). Besides this change in style, they dealt mainly with:

\begin{abstract}
the social frustrations and aspirations of many people of that time, including a concern for the condition of the working and lower middle classes after the war; a discontent that the Welfare State had not reached far enough in eliminating remaining class privileges and inequalities; an implicit criticism of the British class structure; a distaste for the profit motive; a mockery of the old bases of morality and of any kind of gracious living; and a loathing of all forms of pretentiousness (Salwak 2005:23).
\end{abstract}

Jim Dixon, the "hero" of Amis's novel, quickly became regarded as

an

"archetypal angry young man of fiction" (Blamires 1986:220). He is a junior history lecturer at a provincial redbrick university in which he feels out of place; doing a job he wants to keep, but hates, and surrounded by people he does not respect or like. He desperately wants to avoid being 
dismissed after the first year of his two-year probation period. Thus, he tries to be on good terms with his superior, Professor Welch, even though he is the embodiment of everything Dixon hates - he is pretentious, tedious, and snobbish. Dixon has to keep various animosities to himself, so he creates a number of facial expressions that show his true feelings. Malcolm Bradbury observes:

In many respects the book is a traditional romantic comedy: Jim, the comic innocent, trapped in someone else's culture, who always sees that the emperor wears no clothes, receives the comedy's ancient blessing, good luck and good fortune... Jim is a meritocrat who is lifted by social opportunity out of his familiar culture into one he cannot accept or indeed understand. (1994:320)

\subsection{Jim and the Women}

As mentioned previously, the characters in Lucky Jim are seen as either "good" or "bad," as in a fairy-tale. The "bad" characters, Professor Welch and his wife, their son Bertrand, and Margaret Peel, are described as opportunistic, pretentious, and dishonest, while those characters who are likely to gain the reader's sympathy seem to represent their opposite, since they are portrayed as genuine, straightforward, and sincere (Salwak and Koger 2001:12). The most important traits which seem to function as a litmus test for characters are sincerity and straightforwardness. There is a contradiction in the fact that that the main character, who admires the sincerity of others, rarely shows his true feelings to anyone. Jim sees the world as black and white, so people can be divided into two very simple groups - those he likes and those he does not like (Amis 1986:146). His philosophy of life is very simple - nicer things are better than nasty ones (Amis 1986:143). 
Besides Margaret Peel, who is a history lecturer, Amis mentions (only once each) two other women who are also on the faculty: "the sexagenarian Professor of Philosophy" and "the fifteen-stone Senior Lecturer in Economics" (1984:108). Elaine Showalter describes Margaret as "a classic arty bluestocking type" (2005:25). She is portrayed as melodramatic, manipulative, and opportunistic. She goes as far as faking a suicide attempt in order to keep two men in her life under her control by making them feel responsible and guilty about her state. Jim feels he is being tricked into having some kind of relationship with Margaret "by a combination of virtues he didn't know he possessed: politeness, friendly interest, ordinary concern, a good-natured willingness to be imposed upon, a desire for unequivocal friendship" (Amis 1984:10). Without having wanted to, he becomes the only man in her life when her alleged boyfriend leaves her for another woman. Jim always focuses on Margaret's appearance and her lack of good taste in clothing. He is always noticing her poor fashion sense and badly applied makeup. Once he concludes:

\footnotetext{
What a pity it was, he thought, that she wasn't better-looking, that she didn't read the articles in the three-halfpenny Press that told you which colour lipstick went with which natural colouring. With twenty per cent more of what she lacked in these ways, she'd never have run into any of her appalling difficulties: the vices and morbidities bred of loneliness would have remained safely dormant until old age. (Amis 1984: 167)
}

The other woman in Jim's life is Christine Callaghan, who is everything Margaret is not. She works in a bookshop and comes from a wealthy family, with an uncle who is a rich, famous art collector. At first Jim dislikes her, especially because she is in a relationship with Welch's son, who is pretentious and arrogant, but she proves to be more relaxed and 
down-to-earth than he had expected. The moment he sees Christine he notices her good looks, but also the simplicity of her clothes. He feels it is an injustice that women like this are always "the property" of men like Bertrand, while his women were:

\footnotetext{
...those in whom the intention of being attractive could sometimes be made to get itself confused with performance; those with whom a too-tight skirt, a wrongcoloured, or no, lipstick, even an ill-executed smile could instantly discredit that illusion beyond apparent hope of renewal. But renewal always came: a new sweater would somehow scale down the large feet, generosity revivify the brittle hair, a couple of pints site positive charm in talk of the London stage or French food. (Amis 1984:39)
}

For Jim, women like Christine are a valuable "possession" of their men and their worth is measured not only by their looks, but also by the way they dress and their makeup. Jim constantly scrutinises women's physical appearance, their clothes and their makeup. In order to impress him, they are supposed to live up to standards which do not apply to men. Jim is never bothered by the fact that he is not particularly good-looking - he is described as short and with "an unusual breadth of shoulder that had never been accompanied by any special physical strength or skill” (Amis 1984:8). At one point Margaret describes him as "a shabby little provincial bore" (Amis 1984:162). His clothes do not seem to affect his sense of self-worth he has only one decent pair of trousers, because the other respectable pair he owns is suitable only for interviews and funerals and his third one is stained with food and beer (Amis 1984:183). Gavin Keulks says that Jim “instinctively rebels against pretenders, shams, and intellectuals - anyone, that is, who places more value on appearance than substance" (2003:111). While this does seem to be true, it cannot be applied to Jim's own 
perception of women. For women, their appearance is the force that shapes them:

It was all very bad luck on Margaret, and probably derived, as he'd thought before, from the anterior bad luck of being sexually unattractive. Christine's more normal, i.e. less unworkable, character no doubt resulted, in part at any rate, from having been lucky with her face and figure. But that was simply that. (Amis 1984:247)

Jim's obsession with clothes and appearance seems at odds with his dislike of wealthy people and his support for the Welfare State. He desires Christine Callaghan not only because of her good looks, but also because of her good taste, which functions like a status symbol. He detests the elitist high culture of the rich but craves their wealth and the opportunities they have:

Why hadn't he himself had parents whose money so far exceeded their sense as to install their son in London? The very thought of it was a torment. If he'd had that chance, things would be very different for him now. (Amis 1984:182)

Jim does not like the fact that Christine is sometimes too reserved and gracious, but on the other hand he also dislikes Margaret's melodramatic behaviour, which often appears artificial. The literary heroes of the postwar period were better educated than their fathers had been but refused to completely abandon the habits and attitudes learned from their class. Nevertheless, this does not mean that these heroes are happy with their allotted place in the hierarchy of society - they can be highly competitive in order to obtain a better job or a more attractive woman whom they desire. Although they dislike the lack of emotions of the upper class, they envy their effortless composure (Gindin 1976:2). 
Christine is represented as an immature but good-hearted girl. Her character does not evolve much. She is very young and stays in a relationship with Bertrand even though he always "puts her in the wrong", as she says (Amis 1984:142). Her submissiveness is obvious when she is around him:

Bertrand dominated the central group, doing a lot of laughing as he told some lengthy story; his girl watched him intently, as if he might ask her later to summarise its drift. (Amis 1984:40)

Jim notices that she adopts his attitudes and opinions too much, but that would not be a problem if Bertrand were someone he liked:

It was queer how much colour women seemed to absorb from their men-friends, or even from the man they were with for the time being. That was only bad when the man in question was bad; but it was good when the man was good. (Amis 1984:145)

Margaret's role of a "woman as a destructive temptress" (Fallis 1977: 70) is very common in this period, as Brannigan observes:

\footnotetext{
... at a time when women were put under intense social, political and psychological pressure to stay at home and find satisfaction in the roles of mother and wife rather than push for equality, the mainstream literature of the period can be found reflecting misogynist attitudes and blaming women for the minor ills and problems of its male protagonists. (2002:34)
}

Jim manages to free himself from Margaret's destructive power only through sheer luck. Thanks to his chance encounter with a man who drove 
her to her "suicide attempt", both men become aware of her manipulative character.

The two other women in Lucky Jim are Mrs Welch and Carol Goldsmith. Both are married to members of the faculty, but they could not be more different. Jim describes Mrs Welch as a woman who emasculates his superior:

When publicly disagreeing with her husband, for example, she was the only living being capable of making Dixon sympathise with him. (19)

Just like her husband, she seems ludicrous in her elitism and pretentious lifestyle. She and her husband are typical examples of the upper class and the lifestyle which Jim detests.

Unlike Mrs Welch, Carol Goldsmith belongs to the group of the "good" characters. She is one of Jim's allies even though he sometimes feels intimidated by her (Amis 1984:45). She helps Jim get his girl by revealing Bertrand's two-timing behaviour to Christine. She talks about sex very openly, which makes her seem like a forerunner of the turbulent sixties she cheats on her husband but does not lie about it. Carol is the only female character who escapes being represented in a stereotypical way. She behaves in a manner which is not acceptable to her contemporary society since she has no children and is very open about her sexuality. Nevertheless, she gains the reader's (and Jim's) sympathy because of her honesty and sincerity.

With regard to the book's unflattering portrayal of women, Keulks justifies Amis by claiming that he did the same thing to men (2003:165). He claims that Amis wrote "blatantly honest depictions of women" (2003:164). 
Although there are many unlikable male characters in Lucky Jim, women are often generalised about negatively, while men are not:

All the same, what messes these women got themselves into over nothing. Men got themselves into messes too, and ones that weren't so easily got out of, but their messes arose from attempts to satisfy real and simple needs. (Amis 1984: 117)

Dixon wanted to laugh at this. It always amused him to hear girls (men never did it) refer to 'Uncle', 'Daddy' and so on, as if there were only one uncle or daddy in the world, or as if this particular were the uncle or daddy of all those present. (Amis 1984:49-50)

\section{Conclusion}

An analysis of the representation of women in Lucky Jim makes it seem only natural that in the 1960s Kingsley Amis should have turned dramatically to the right - he supported the American war in Vietnam, which was very rare for writers of the time, and he expressed worries about the Communist threat, feminism, the Labour Party, and the Welfare State (Moseley 2005:303). Many critics believe that postwar literature was actually conservative and reactionary (Brannigan 2002:5). Such critics hold that the conflict in 1950s literature was not between conservatism and socialism, but between the old and the new conservatism. The old conservatism came from the upper and upper-middle classes and was characterised by their fascination with empire and elitism. The new conservatism was founded on anti-elitism and anti-intellectualism, as well as on a dislike of empire and of foreignness in any form (Brannigan 2002:21).

The Angry Young Men as a group, of which Amis was certainly a member, appear not to have had a problem with the conservative order, but 
only a problem with their place in that order (Brannigan 2002:12). They popularised the new conservatism of the postwar period, which celebrated individualism, free market economics, and consumerism (40). This focus on consumption is apparent in Jim's attitude towards women since he pays a great deal of attention to their clothes and makeup. Women are expected to consume in order to be considered attractive. The support of the movement's literary characters for the Labour Party and the Welfare State served as a way to shock the Establishment, which did not accept them (Gindin 1976:46). For example, the working class is ridiculed when Jim imitates their ignorance of grammatical rules and orthography (Amis 1984:157). When Jim talks to one of his colleagues, he agrees with the colleague's opinion that there are too many students on Education Authority grants and that this will lead to schools "full of teachers who couldn't pass the General Certificate themselves, let alone teach anyone else to pass it" (Amis 1984:74).

In a fairy-tale ending, Jim gets both the job that Bertrand wanted and Bertrand's girlfriend. Bertrand is a representative of the "old order" which is satirised in Lucky Jim. His arrogance is best seen in his statement:

\footnotetext{
When I see something I want, I go for it. I don't allow people of your sort to stand in my way. That's what you're leaving out of account. I'm having Christine because it's my right. (Amis 1984:212)
}

Jim indeed gets both the girl and the job instead of Bertrand, despite this having nothing to do with his actions; it is the consequence of his good luck. He gets the job not because he has the qualifications, but because he does not have any disqualifications (Amis 1984:238). Jim manages to get the position he wants because he appears to be straightforward and down-to- 
earth, unlike Bertrand. Christine decides to leave Bertrand because in the end she finds out that he is also seeing Carol Goldsmith. Although Jim knows this, it is Carol who reveals it to Christine. Jim's fairy-tale ending has nothing to do with his abilities or actions; it is simply the result of sheer luck and his lack of pretentiousness. And while this fairy-tale ending bestows upon Jim both the girl he wants and a better job, all it does is to confirm that the lower class can advance only by mere chance (Brannigan 2002:37). Additionally, Jim's advancement in the hierarchy of class through his getting a girl of higher social standing allots women the role of a mere object, of a status symbol.

\section{References}

Amis, Kingsley. 1984 (1954). Lucky Jim. London: Victor Gollancz Ltd.

Blamires, Harry. 1986 (1982). Twentieth-Century English Literature. London: Palgrave Macmillan.

Bradbury, Malcolm. 1994. (1993). The Modern British Novel. London: Penguin Books.

Brannigan, John. 2002. Literature, Culture and Society in Postwar England, 1945-1965. Lampeter: Edwin Mellen Press.

Davies, Alistair. 2000. "From Welfare State to Free Market" in British Culture of the Postwar. Alistair Davies and Alan Sinfield (Eds.). London-New York: Routledge, pp. $51-57$.

Fallis, Richard. 1977. “'Lucky Jim' and Academic Wishful Thinking” in Studies in the Novel 9 (1): 65-72.

Gindin, James. 1976 (1963). Postwar British Fiction: New Accents and Attitudes. Santa Barbara: Greenwood Press.

Keulks, Gavin. 2003. Father and Son: Kingsley Amis, Martin Amis and the British Novel since 1950. Wisconsin: University of Wisconsin Press. 
Moseley, Merritt. 2005. "Amis, Father and Son" in A Companion to the British and Irish Novel 1945 - 2000. Brian W. Shaffer (Ed.). Oxford: Blackwell Publishing, pp. 302-313.

Salwak, Dale and Grove Koger. 2001. "Kingsley Amis" in Notable British Novelists, Volume 1. Carl Rollyson (Ed.). Pasadena: Salem Press, pp. 6-20.

Salwak, Dale. 2005. "The 'Angry' Decade and After" in A Companion to the British and Irish Novel 1945-2000. Brian W. Shaffer (Ed.). Oxford: Blackwell Publishing, pp. 21-31.

Showalter, Elaine. 2005. Faculty Towers: The Academic Novel and Its Discontent. Philadelphia: University of Pennsylvania Press.

Spencer, Stephanie. 2005. Gender, Work and Education in the 1950s. New York: Palgrave Macmillan.

Womack, Kenneth. 2002. Postwar Academic Fiction. New York: Palgrave. 